\title{
Recognising mitigation: Three tests for its identification ${ }^{\text {th }}$
}

\section{Cristina Villalba Ibáñez}

Facultat de Ciències Humanes i Socials, Departament de Filologia i Cultures Europees, Universitat Jaume I, Av. de Vicent Sos Baynat s/n, 12071, Castelló de la Plana, Spain

\section{A R T I C L E I N F O}

\section{Article history:}

Received 11 April 2020

Received in revised form 15 June 2020

Accepted 30 June 2020

Available online 26 July 2020

\section{Keywords:}

Mitigation

Methodology

Analysis

Tests

\begin{abstract}
A B S T R A C T
Linguistic mitigation is a pragmatic phenomenon that has been profusely treated in the literature, and yet there are few studies dedicated exclusively to offering methodological criteria for its recognition and analysis (but see Albelda, 2010 and Albelda et al., 2014). Consequently, the researcher must infer the methods for its recognition through problems arising during the analysis or through the examples and reflections offered by the authors who have addressed the issue. The purpose of this article is twofold. Firstly, to present some of the main keys for the recognition of mitigation presented by the bibliography, such as the catalogues of mitigation devices, the context, the face and the illocutionary force. Secondly, this text problematizes Villalba's (2018) proposal for the identification of mitigation based on three tests: the absence test, the commutation test, and the solidarity test. In order to do that, we apply this test to a corpus of examples of mitigation extracted from research articles that study this phenomenon. After that, we reflect on the problems the tests or the examples may present to the researcher. The proposal, in conjunction with the traditional criteria, aims to offer strategies in order to facilitate the analysis of mitigation.
\end{abstract}

(c) 2020 Elsevier B.V. All rights reserved.

\section{Introduction}

Offering a definition and criteria that allow a clear recognition of the object of study is one of the main challenges researchers have to address when facing the study of any phenomenon. In the case of mitigation, we can find numerous studies that try to account for this phenomenon from a theoretical point of view accompanied by the analysis of examples (see Bazzanella et al., 1991; Briz, 1995; Brown and Levinson, 1987; Caffi, 1999; Fraser, 1975; Holmes, 1984; Meyer-Hermann, 1988; Sbisà, 2001; Schneider, 2013). Although not all authors use the same terminology and many address the study from different theoretical frameworks, authors agree that mitigation relates to the attenuation of certain aspects in the discourse in order to reach a communicative goal.

As Albelda and Estellés (this volume) pointed out, mitigation has been associated with the idea of gradation, illocutionary force, face and strategy. Mitigation can be defined as a rhetoric-pragmatic strategy related to the management of face that aims to soften eventual negative effects in communication (Albelda and Briz, in press).

A clear definition of mitigation is needed in order to carry out any research about this phenomenon. However, when facing corpus, some questions may arise about how mitigation can be properly identified, and there are few studies dedicated exclusively to discussing methodological aspects for its analysis. Different authors and theories focus on a variety of factors,

\footnotetext{
* This research is framed in the project Es.Vag.Atenuación: Pragmatic attenuation and its genre variation: written and oral discursive genres in European and Latin American Spanish (MINECO: FFI2016-75249-P).

E-mail address: villalbc@uji.es.
} 
such as the identification of the illocutionary force, the importance of mitigation for face management (no matter if it is oriented to one's face or another's), the use of certain forms or the context. All sources present these aspects in an abstract way, and it can be difficult to apply their definitions as a methodological tool for the analysis.

We provide, firstly, a revision of the criteria offered by the literature to assess mitigation. Secondly, we present the methodology used to carry out this research. We will conduct three complementary tests based on Villalba (2018) that can help the researcher to assess if mitigation is present in his/her data: the absence test, the commutation test and the solidarity test. Next, in the results and discussion section, we will comment on some particular cases found in our data that can become a challenge in the analysis. We then will dedicate a final section to offering some directions on the issues related to the methodological recognition of mitigation that need to be addressed in the future.

\section{Some criteria related to the analysis of mitigation}

In this section, we present a revision on the criteria offered by the literature to assess mitigation. These criteria include the use of catalogues of linguistic forms, the examination of the context and discursive genre, the presence of face management and the reduction of the illocutionary force.

\subsection{Catalogue of linguistic forms}

It is common to present, along with a definition of mitigation, a catalogue of linguistic devices that (usually) convey mitigation. Examples include Albelda et al. (2014), Albelda and Cestero (2012, 2011), Bazzanella et al. (1991), Briz (1998, 1995), Félix-Brasdefer (2004), Holmes (1984) and Meyer (1997). Codification of mitigation has experienced different degrees of conventionalization, especially when related to showing deference to the addressee (that is, when mitigation and politeness combine), but also in relation to the self. Conventionalization is an expectable consequence of a continued use of a linguistic device in order to achieve a determined goal in a given situation. Put simply, if a speaker observes that, through the use of certain expressions, $\mathrm{s} /$ he is able to satisfy his/her needs and project a positive impression of him/herself, it is logical for them to keep using those expressions to achieve similar results on other occasions.

Regardless, it is paramount to remember that mitigation is a pragmatic phenomenon and, as such, it is directly constrained by the context. Therefore, no linguistic device can be considered a mitigating device without an evaluation of other parameters. Below are a few examples in which a diminutive suffix appears. The diminutive is a linguistic device usually included in mitigation catalogues in Romance languages. Both examples are from Facebook groups.

\footnotetext{
(1) [AMIGOS] [Dirigiénose a otro usuario] ya te han contado lo malito que me puse. Tenía razón [Nombre], el líquido gallego me mató (Maíz-Arévalo, 2018, p. 45) [FRIENDS] [Addressing another user] they've already told you how bad(+diminutive) I got. [Name] was right, the Galician liquid killed me (2) [Una usuaria muy participativa abandona el grupo de Facebook]

Hala! Qué me he perdido? ....tendrás tus motivos pero no lo entiendo (...) desde q estoy aquí, ya he visto varias veces esto mismo y me sorprende ... Todos somos mayorcitos ... ${ }^{1}$
}

[A very active member leaves the Facebook group]

(Maíz-Arévalo, 2018, p. 45)

Wow! What have I missed? (...) Since I'm here, I've seen this several times and it surprises me ... We're all grown-ups (+ diminutive) ..

In (1), it seems like the speaker had too much Galician marc and became drunk. The use of the adjective with the diminutive malito is a way to mitigate the complaint about his health in order to avoid the mockery of other participants in the Facebook group (Maíz-Arévalo, 2018, p. 45). In (2) we also have a diminutive, mayorcitos; however, in this case the diminutive reinforces the argument that all participants are adults and should behave as such.

There are studies that explain the co-presence of mitigation and argumentative reinforcement as complementary phenomena (see Albelda, 2016a, 2016; Estrada, 2008; Kern, 2017; Kotwica, 2018). These studies problematize other aspects related to the use of catalogues of forms as a criteria, such as the impossibility to systematically include some linguistic mechanisms that mitigate. In this sense, González García and García Ramón (2017) reflect on the fact that rejections to invitations are usually codified with linguistic devices linked to reinforcement, as can be seen later in (14).

Catalogues of linguistic devices are useful when facing the analysis of mitigation. However, as a pragmatic phenomenon, examples (1) and (2) show that context is paramount to properly assess whether mitigation is present or not, because mitigation is a context-dependent implicature.

\subsection{The context: where should the analyst look?}

From the perspective of discourse analysis, context can be understood as the collection of factors that constrain the production of an utterance as much as its meaning (Brown and Yule, 1983; Song, 2010). We may find among those factors a

\footnotetext{
${ }^{1}$ For reasons of space, in some cases, examples have been shortened.
} 
myriad of aspects that account for the complexity of any communicative act: the role and position of the participants, the time and space where the communication occurs, the register expected and used in the exchange, the possibilities offered by the channel of communication, the social and cultural values, the co-text and more. In this sense, Levinson (1983, p. 22) points out that the key to making a proper interpretation is to select only those factors that are culturally and linguistically relevant in relation to the production and interpretation of an utterance. As for mitigation, discursive genre seems to be the conjunction between language, which is used to codify the information uttered, and culture, as a genre is a cultural product shaped through time (Swales, 1990). This is why many authors believe that the discursive genre is particularly relevant when it comes to analysing mitigation (Cock et al., 2018; Figueras, 2018; Hyland, 1996; Villalba, 2017).

Following this idea, Albelda (2018) explains that, when comparing the presence of mitigation devices in different discursive genres (informal conversation, messages in a forum, expert colloquiums on TV, presidential debates and research articles), each discursive genre favoured the presence of different strategies related to mitigation. Among these strategies, different devices were used. In other words, the mechanisms used to display mitigation and the way mitigation is linguistically presented in academic genres (Hyland, 2002, 2001; 1996; Markkanen and Schröder, 1997; Meyer, 1997) is different than how mitigation is configured in court (Martinovski, 2006; Villalba, 2017) or in medic consultation (Caffi, 2007, 1999; Hernández Flores and Rodríguez Tembrás, 2018). Compare these examples extracted from an interview (3) and a research article (4):

(3) [La hablante ha explicado que ella iba a un colegio religioso y comenta cómo era la educación en sus tiempos]

I: yo iba al colegio/ y /mis hermanos // había el instituto también // pero bueno / estaba / posiblemente un poquito menos considerado

PRESEEA-SCOM_M33_005

[The speaker has explained she went to a religious school and comments on how education was back in her times]

I: I went to a school/and/my siblings // there was a high-school too // but well / it was / possibly a little less well-regarded

(4) Possibly, phosphorylation of ACC synthase could contribute to the existence of its different pi forms Alternatively, phosphorylationdephosphorylation may be involved in the inactivation/activation of the enzyme in vivo

(Hyland, 1996, p. 435)

First of all, it needs to be outlined possibly is consistently more frequent in research articles than in less formal genres, such as daily conversations and interviews. This points to an specialization of this particular device in certain communicative spaces. Secondly, in both examples, possibly encodes mitigation but in a different way. In (3) the use of mitigation is oriented to protect the speaker' face because she does not want to be seen as an elitist person. In contrast, the use of possibly in (4) is related to the researcher role of the speaker. He or she presents his/her claim with caution because later investigation can confirm (or prove to be wrong) this conclusion. Therefore, cautiousness when presenting claims is required to properly build their face as members of the scientific community. In addition, this apparent lack of certainty is also a way to show deference to the scientific community, that can have a say about the validity of the issues presented (Hyland, 1996).

Context is a complex and vast parameter to work with systematically while analysing data. Bibliography about mitigation shows that the discursive genre can be the key parameter to better assess the presence of mitigation. We agree genre is extremely useful, as it provides a framework to understand how and in what way mitigation is conveyed. However, if we understand communication as a dynamic situation where our goal, our knowledge and our relationship with the other party evolves as the interexchange progresses, we will need to add an extra parameter to work in conjunction with the discursive genre.

To this end, Briz and Albelda (2013) present a systematic way to analyse mitigation through the general, interactive context (GIC) and concrete, interactive context (CIC). GIC can be defined through the register and the discursive genre where the analysed excerpt is framed. In contrast, CIC refers to the specific segment, utterance or exchange where mitigation occurred. CIC is articulated in three parts: the trigger (what motivates the appearance of mitigation); the mitigating device (what mitigates); and the mitigated element (that which is directly affected by the mitigating device).

We find this methodological contribution particularly useful because it provides a pattern to describe how mitigation is encoded, and it forces the analyst to reflect on the general situation and find the trigger that confirms the strategic role that mitigation plays.

\subsection{Face management is always present}

Face is a concept that refers to the positive attributes a person claims for himself and wants others to recognize during the interaction (Goffman, 1955, p. 222). Recent research explain face as a multifaceted concept where cognitive, psychological, cultural, interpersonal and, of course, social aspects interact (Garcés-Conejos Blitvich, 2013; O'Driscoll, 2017). In the case of mitigation, an operative definition of face relates to the attributes of the self (cultural, relational and personal) that are updated in the self-presentation (that is, the control the speaker has over the information of the self), and are claimed during the interaction (Figueras, 2018, p. 267). The advantage of this definition is that it is comprehensive and offers keys to the analyst about what aspect in the example triggers the use of mitigation.

The early works on mitigation addressed the study of this phenomenon frequently in relation to the social dimension and, more specifically, to politeness (Brown and Levinson, 1987; Fraser, 1980). The attention paid to preserve the interlocutor's face was usually performed through mitigation devices; consequently, mitigation was understood as a politeness resource. Nevertheless, it is inaccurate to systematically link mitigation to politeness due to two main reasons. First, not all mitigating 
devices are oriented to preserve the addressee's face. As we saw in example (1), the speaker used the diminutive as a means to protect his own face. Second, not all shows of politeness rely on the use of mitigation (Hernández Flores, 2013; Schmidt, 1980). In fact, one can boost though linguistic devices a positive attribute and that can be considered a case of politeness. An example would be when someone praises a meal a host has prepared.

It has been problematized the importance of face as an explanatory parameter for the identification of mitigation. Focusing only on the linguistic aspect of mitigation leads some works to develop a definition where face is not present and where mitigation without face is possible (Albelda et al., 2014; Briz, 2007; Cestero Mancera, 2015). The example below was presented by one of these authors:

(5) Mamá, me he hecho un rotito en el pantalón [El niño lleva el pantalón destrozado]

Mom, I've made a little hole in my trousers [The child has the trousers torn]

$$
\text { (Briz, 2007, p. 12) }
$$

According to Briz, the child's goal is to avoid or diminish the reprimand from his mother, but no facework is present in the utterance. His strategic description of his clothes is oriented to ease his relationship with his mother and present himself as a good boy who made something unimportant. Furthermore, the hole is not large, and will not take long to fix. If we accept that this subtle communication is taking place in the example, then there is a negotiation of face. We conclude, as do most researchers in this field, that mitigation is a linguistic, but also a social, phenomenon. Thus, the presence or absence of face management becomes a parameter to assess mitigation (Albelda, 2016b; Thaler, 2012). Compare these two examples related to vague language:

(6) [The lawyer is inquiring for the type of sound the witness heard] Q. Right. It's not a long "Mmmmmmmmmmm"?

A. No, sort of "Beep, beep, beeep", sort of - you know, that sort of thing.

(Cotterill, 2003, pp. 102-103)

(7) [In a Mathematic class, the teacher asks the student about an arithmetic operation]

Tim: I'd just like you to sort of say how many you think there would be, say for the number 24 . / ... / Rebecca: / ... / 22? No, not 22 ways. 12 ways?

(Rowland, 2007, p. 90)

In (6), the use of sort of is motivated by the inability of the witness to blare like a car's horn, but there is no facework. In contrast, in (7) the teacher does not want to be domineering and make the student unwilling to participate. This second example is a case of mitigation, because a management of face is involved.

As there is no mitigation without face, the identification of facework in relation to the characteristics of the context and the expectations of the discursive genre become indispensable criteria to assess the presence of mitigation. This is especially true in cases where semantic phenomena, such as vagueness, are present (Overstreet, 2011).

\subsection{Illocutionary force and speech acts}

Traditionally, definitions of mitigation have pointed to the reduction of illocutionary force as a key element in its assessment (Bazzanella et al., 1991; Briz, 1998, 1995; Caffi, 1999; Holmes, 1984; Sbisà, 2001). In other cases, scales related to the epistemic commitment or the degree of obligation have been presented as explanatory principles for the use of mitigation (Czerwionka, 2012; Meyer-Hermann, 1988).

In relation to the illocutionary force and speech acts, the literature usually takes the evaluation of the felicity conditions as a methodological criterion. Thus, the abstract characteristics of the act are related to the way in which it has been formulated to be analysed in the excerpt (Caffi, 2007; Thaler, 2012). If the illocutionary point of the speech act has been downgraded and the face is affected (see 2.3.), we will confront a case of mitigation.

Regarding the types of speech acts, the identification of mitigation in directive acts poses the least problems, since the relational management is evident as the speaker mobilizes the addressee to do something. Furthermore, there are formulas (some of them very conventionalized, like please, would you mind ...) to meet this discursive goal.

The study of mitigation in expressive speech acts is traditionally linked to the assessment of critiques and apologies. As with directives, the use of mitigation in expressive speech acts can sometimes appear through conventionalized forms, such as, don't get me wrong but ..., to prevent a damage, or I'm sorry, I apologize to repair the other's face once the damage is done.

The challenges arise when analysing commissive and assertive acts. On the one hand, commissive acts have hardly been analysed in relation to mitigation (but see Kern, 2017), perhaps because they are usually interpreted as a speech act without gradation (it is or it is not a promise). Nevertheless, when analysed in detail and with the help of mitigation, these speech acts can experience a gradation of commitment that the speaker establishes with his future action. Compare I will deliver my manuscript on time to If I don't have too much work, I will try to deliver my manuscript on time. The commitment in the first case is greater than in the second case.

On the other hand, the analysis of assertive speech acts usually poses problems, especially when it comes to assertions about the objective description of reality (in contrast with the subjective description of reality, which manifests through 
opinions). In cases where the epistemic compromise is reduced in subjective assertions (opinions), it seems easier to identify cases of mitigation. This happens because opinions are closely related to the way in which the speaker presents their own face and treats the other (if the opinion is addressed to the hearer). Since opinions can cause controversy and alter the way others see us or our relationship with the addressee, it is not strange to seek the acceptance of others through linguistic resources that mitigate our statement or our commitment to it.

There are more problems assessing mitigation when assertive acts are related to objective descriptions. This confusion comes from the fact that "the researcher cannot access the intention of the speaker and the linguistic forms used are insufficient to assess without doubt if mitigation is present" (Albelda, 2010, p. 9). Compare these two examples:

(8) [Tres vecinas hablan sobre cuánto pagaron por el impuesto de circulación]

M: yo el año pasao pagué del mío siete mil y pico

E: yo creo que eran siete mil novecientas o seis mil

(...)

M: y lo que me ha chocao $\uparrow$ es que siendo un Forito digo es que a lo mejor hay un tope $\rightarrow$

E: no lo [sé]

M: [que] aunque pasen dos o tres o equis caballos más $\rightarrow$ pagarán lo mismo

(Albelda, 2010, pp. 13-14)

(Three neighbours are talking about how much they paid for the road tax)

M: last year I paid seven thousand and something for mine

$\mathrm{E}$ : I think it was seven thousand nine hundred or six thousand

( ...)

M: and what has shocked me $\uparrow$ is that being a little Ford I say maybe there is a limit $\rightarrow$

E: I don't know

M: even if it is two or three or more horsepower up $\rightarrow$ they'll pay the same

(9) E: y luego ee// ¿hay muchoo-mucho ambiente juveniil?

I: sí

E: ¿sí?/mm mm

I: mucho mucho/ ¡bueno mucho muchoo/ no sé!

(Albelda and Cestero, 2011, p. 17)

$\mathrm{E}$ : and then ee // is there a very - a very youthful atmosphere?

I: yes

E: yes?/mm mm

I.: very very / well very very / I don't know!

To better analyse these examples, Albelda (2010) presents three tests. These tests take into account: the degree of integration in the segment of the form candidate to be analysed as a case of mitigation (test 1); the presence of reformulations or corrections (test 2); and "the anticipation of certain elements to words that, in the speaker's opinion, may have a negative effect" (test 3) (Albelda, 2010, p. 64). Taking into account test 1, example (9) constitutes a case of mitigation. I don't know is modifying very, and therefore is integrated in the act. It is also involved in a reformulation movement, which confirms test 2. In contrast, I don't know in example (8) constitutes an independent utterance that is not a reaction to a previous interpersonal intervention. Instead, it neutrally reveals a state of facts: the speaker just does not know that information.

This methodology can be useful for the analysts, since it provides general indicators that are frequently related to the presence of mitigation, but these tests are designed to address one type of speech act: assertives, as it relates to the commitment the speaker establishes with the utterance. This makes this methodological contribution insufficient but useful for these particular speech acts.

In conclusion, the analysis of mitigation faces new challenges and the fact that analysts still have doubts when assessing some elements as cases of mitigation is a sign that the criteria provided, such as catalogues of forms, the context, the presence of facework or the illocutionary force, need further reflection. We need a methodology abstract enough to address all types of speech acts in different contexts, but not too abstract, as it needs to be easy to apply. This way, analysis from different researchers will be more unified.

\section{Corpus and methods}

The tests we present later attempt to provide some guidance to the analysts when determining whether or not a case of mitigation is present. These tests (the absence test, the commutation test and the solidarity test, roughly presented in Villalba, 2018) have been inspired by our own experience analysing data and the comments that experts make in their research to prove that they are facing a case of mitigation. In order to validate the tests, we have created an unconventional corpus with examples from the studies cited throughout this paper that address aspects related to mitigation.

\subsection{Corpus}

Since the goal was to assess the suitability of our tests, we needed examples of mitigation validated by the scientific community. The works from which the examples were extracted address the study of mitigation through the analysis of 
general corpus and corpus of specific genres, such as conversations, medical consultations, research articles, interactions in different social networks, online discussion forums, parliamentary speeches, trials and interviews. ${ }^{2}$ In addition, examples created ad hoc by the authors are also included (this is characteristic of the first works on mitigation ${ }^{3}$ ). In regard to languages, the examples included are primarily in English and Spanish but also other languages (such as Italian, French or Bulgarian) with the English translation.

The selection criteria of the examples for our corpus relied on the following factors: a) the author of the referenced work acknowledged that s/he is facing a case of mitigation; b) the context of the example collected is recoverable in the referenced work and is sufficient without requiring a great explanation. We have also collected examples where the presence of mitigation is discarded by the author of the referenced work in order to better assess whether the application of our tests is adequate.

\subsection{Three tests}

From a strictly linguistic point of view, mitigation generates an implicature through indirectness of what is stated and the true intention of the speaker (Albelda and Briz in press). Hence, the analysis of mitigation entails a clear identification of the characteristics of the context (register and genre), the purpose and attributes of the face of participants and the characteristics of the speech act. Once those are identified, these tests can be applied independently or, if possible, complementarily, as we will see in more detail in Section 4.

\subsubsection{The absence test}

In cognitive terms, encoding and decoding a message is costly. Consequently, one might expect that, as participants in an interaction, we would use the least marked and simple ways possible to communicate. This does not always happen. Compare (10a) and (10b).

(10a) T. io le proporrei se vuole una medicina apposta per vedere se riesco a farla dormire.

P. hmm (PsV)

T. I'd propose, if you like, a special medicine, to see if I can make you sleep.

P. hmm

\section{T. (Take) this special medicine}

(Caffi, 1999, p. 892-893)

It is easy to imagine the General Interactive Context (GIC): a doctor-patient interaction in a clinic during a consultation. After examining and listening to his patient, the trigger for the use of mitigation in this Concrete Interactive Context (CIC) is when the doctor prescribes the treatment. In (10a) we have a suggestion. In (10b) the doctor is also prescribing a special medicine, but without what is marked in bold in (10a): the hedged performative verb (I'd propose), the concession to show that the prescription is up to the patient to take (if you like) and the justification of or reasoning for his suggestion, making it more palatable (to see if I can make you sleep). The changes between the two examples can be tracked in the illocutionary force or, in terms of face, in the relationship between the participant and the speaker's faces. Then, we will have a compelling argument to think that what has been erased is related to mitigation.

The absence test is particularly useful to apply with linguistic formal resources, such as lexic modifiers ( $a$ bit) or probability markers (possibly). Furthermore, it can also be useful to apply this test in discursive segments where mitigation is built through the succession of turns.

(11) [One friend to another]

Oh you've had your hair done -

It looks great (three turns intervene)

Oh that reminds me are you free to babysit tonight? ${ }^{4}$

(Holmes, 1984, p. 362)

In (11) the GIC is a conversation between friends. If we focus on the CIC, we notice that the speaker wants the addressee to do something for her. This is the trigger that sets the strategic use of mitigation. Instead of asking directly,

\footnotetext{
2 The selection of different genre aims to show the applicability of the tests to any corpus, no matter if written or oral. However, if the analyst works with oral corpus and has access to the recordings, it will be helpful to take also into account phonic parameters, as they can encode mitigation alone or combined with verbal devices (Estellés and Cabedo, 2017).

3 The use of examples ad hoc in works about mitigation was quickly replaced by examples extracted from corpora. This was a necessary methodological improvement (Briz and Samper, in press) that enhanced the studies about this phenomenon. According to our view, presented in Section 2, the recognition of the context provides the optimal frame to apply the tests we present in this work in order to assess mitigation. It is true that examples ad hoc are sometimes preceded by an explanation of a plausible situation where the excerpt could be uttered, but is not as enriched as a real context.

${ }^{4}$ In the original example, there is no question mark, probably due to an error in the transcription.
} 
she praises the addressee's appearance then asks her to babysit her child. If we erase the utterances presented before the petition, it becomes more demanding and, perhaps, the possibility of achieving the speaker's communicative goal become scarcer.

In our analysis of the data, the absence test is the most consistent, as it connects with the cognitive principle of marked forms denoting marked meanings (Levinson, 2000). This is why it should be applied first in our analysis whenever possible.

\subsubsection{The commutation test}

Sometimes a form or a segment in the discourse cannot be erased for several reasons, as presented in the absence test. For example, the result can be grammatically incorrect (or at least pragmatically strange in a given situation) as in (12b), or it could just not be possible to eliminate a single element because the main sense of the utterance will be lost (13).

(12a) D. c'è un'i: perplasia estrogenica - c'è scritto qui. (SV)

'there's an estrogenic hyperplasia - it is written here'

(Caffi, 1999, p. 8966)

(12b) D. i: perplasia estrogenica - c'è scritto qui. (SV)

'estrogenic hyperplasia - it is written here'

In (12a), we have an interaction between a doctor and her patient. The CIC that triggers the use of mitigation is the fact that he is informing a patient about a condition (estrogenic hyperplasia). To do that, D uses a non-agency construction (c'è/there is) as a means of distancing the interlocutor from the disease (which is a negative aspect). Linguistically, the estrogenic hyperplasia just exists, and, through an inference, we connect it with the patient. A second resource is the presentation of an external source (probably a medical report) that eliminates the presence of the "I" and reinforces the credibility of what is stated by showing objectivity (it is not the speaker who have reached the diagnosis and carries bad news, but this report).

In this example, the absence test can be applied to the second mitigating device; however, it is difficult to erase the nonagency construction without getting an ungrammatical utterance or, at least, without making it necessary to add more context to properly understand what the doctor is saying. In these cases, we need to think about what other forms can commute without losing the main meaning, identify what can be considered neutral (taking into account linguistic and context factors in its most comprehensive definition) and assess if the form used in the utterance we are analysing is below or above the neutral form when ordered on a scale. For instance, the doctor could have said: you have estrogenic hyperplasia or you suffer (from) estrogenic hyperplasia. The first one is a construction with an agent presented through the verb have. This verb is quite neutral in its meaning, in comparison with suffer, which relates to a bad condition and pain. If we order these three utterances on a scale, it would look something like this:

(12c) - There's an estrogenic hyperplasia.

0 You have an estrogenic hyperplasia.

+ You suffer from estrogenic hyperplasia.

Since mitigation is related to gradation, it is usually easy to convoke elements that could replace the current element candidate to develop mitigation. Then one can see if the use of one or other form causes changes in the illocutionary force, in the relationship between participants or in the speaker's face. In this case, one can observe the doctor's concern as he tries to be tactful with his patient.

The commutation test can also be applied when we cannot erase what we think is a mitigating device because the main sense of the utterance will be lost. This occurs in the example below. Notice the use of beer in this excerpt from a trial where the prosecutor $(\mathrm{P})$ is cross-examining the defendant $(\mathrm{D})$.

(13) $\quad$ P: < men den här aktuella kvällen eftermidda kvällen da ${ }^{\circ}$ hade du druckit sprit $>$ /

$\mathrm{D}:<$ (ja) öl ja ga ${ }^{\circ} \mathrm{r}$ mest $\mathrm{pa}^{\circ}$ öl $>$

$\mathrm{P}:$ ' $<$ but that particular evening afternoon evening then you had been drinking

liquor $>$ ' @ $<$ mood: asking $>$

D: $<$ (yes) beer I mostly do beer $>$ @ < quiet $>$

(Martinovski, 2006, p. 2074)

We see some mitigating devices in D's utterance triggered by the necessity to elaborate a discourse that can attenuate the penalty if $\mathrm{D}$ is found guilty. The commutation test can help us evaluate these devices. To begin, the defendant partially admits to be drinking and makes a correction to reduce the anticipated accusation. It can be labelled as some sort of concessive structure. If he would have only answered yes, he would have admitted that he had been drinking strong alcohol such as vodka, whiskey or gin that day. However, the defendant strategically clarifies he drinks beer (and not any harder alcohol). All possibilities ranked, beer has less ethanol and, according to D's statement, it sounds like he drinks beer frequently (one may think he is more used to its effects than a person that just drinks beer occasionally). The way $\mathrm{D}$ responds is evasive because he is not directly answering the question of what he drank that specific day, but instead spends time talking about what he usually drinks. 
In addition, D's deposition is stated in a quiet voice, according to the notation. Prosodic devices, such as intensity, frequency, type of tone, modulation or elongation can appear alone or in combination with lexic/verbal devices in order to mitigate (Cabedo, 2016; Estellés and Cabedo, 2017). Given the context and the fact that it is the prosecutor (and not his own lawyer) who is asking, we assume that drinking may have some negative impact on the case and face of D. Consequently, D utters his answer in a very low voice to reduce the admission of guilt.

In short, as different possibilities of what he could have answered and in what tone it could be stated present themselves, we rank them and reach the conclusion that this utterance is mitigated.

The commutation test works better with cases of mitigation that are directly related to the way the utterance is built. For example, when there is a will to de-focus the participants of the interaction, as happens with impersonality (I will not accept this document - This document will not be accepted), or with the use of a lexic selection to reduce some unwelcome effects, as occurs in euphemisms (He is dead - He passed away). It is also a valuable test to apply when indirect speech acts appear, as in (14).

(14) [Evento de Facebook donde se invita a los participantes a un recital de poesía]

Yo quiero irrrrrrrrrrrrrrrrrrrrrrrrrrrrr. Correcher y Zapater, que además de rimar entre sí, son dos poetazos que para qué. Resignación

González García y García Ramón (2017: 144)

[Facebook event where participants are invited to a poetry recital]

I want to goooooooooooooooo. Correcher and Zapater, that, besides rhyming each other, are two prodigious poets (+aumentative). Resignation.

This is an example of a rejection to attend to an event. Following the commutation test, the speaker could have said "I won't go" or, in this particular case, he could just have clicked the button "No" that used to appear in this kind of interactions on the social network. Because a rejection is a dispreferred answer, mitigation could be expected. However, what we find here is the use of several linguistic resources related to intensification. Does this mean the rejection is boosted? As González García and García Ramón explain, that is not the case. The speaker intensifies his desire to go and emphasizes the quality of the poets, but this is a strategy oriented to mitigate the rejection and take care of the faces involved in the act that could be damaged due to the refusal.

In conclusion, unlike the absence test, where the elimination of the form can be applied effortlessly, the commutation test demands from the analyst to propose plausible alternatives and range them on a scale. The ability to present different forms relies on the analysts' linguistic knowledge and creativity (which can vary from researcher to researcher). This is why this test is fairly consistent, but less than the precedent test.

\subsubsection{The solidarity test}

Mitigation is frequently displayed in one speech act by more than one device (Albelda et al., 2014, p. 41; Caffi, 2007, pp. 112, 229; Thaler, 2012, p. 915). In fact, if we revisit all the examples presented for the tests above, we realize that all of them portray more than one mitigating device. In this sense, we have observed that when there are different devices in a specific segment and we are not certain if one of those devices has a mitigating value, we need to assess whether there are other mitigating devices near it. If so, it is possible that our device will also act as a mitigating device. Below is an excerpt from an interaction between a doctor and a patient. Can we consider start modifying a mitigating device in (15)?

(15) Dr. B: lo que se debe hacer es/ir modificando un poco/[el es-=]

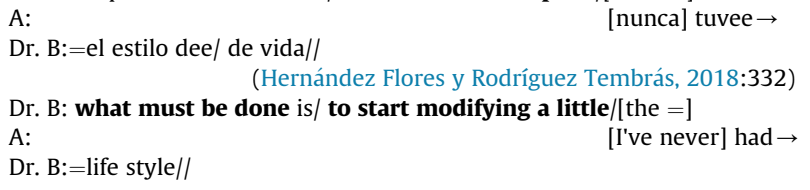

The GIC (the medical consultation) is a space where there is a hierarchical relationship between the participants and where prescriptions and advice are frequently made to improve the health of the patients. This is what happens in this specific excerpt; the trigger is the suggestion that the lifestyle needs to be modified (CIC). The conflict is generated because the patient's diet is in question and her face is threatened. The doctor wants his recommendations to be well-received and to prevent a possible rejection by reducing the degree of obligation in his statements. There is a deontic periphrasis with a mechanism that de-focuses the agent, and an approximative (a little), that also minimizes the intensity of the change that the patient should develop. All these devices together make us think that start modifying has a mitigating orientation, too. In fact, if we analyse this construction and apply the commutation test, we realise that the doctor could have said modify, but instead he chose to present the change in the diet as a long-term process.

The solidarity test is deeply related to the identification of linguistic devices conveying mitigation, and, perhaps because of this, it is the least consistent of the three tests presented. In our analysis, we have gathered cases like (16), where we may wonder if Forston's intervention is mitigated or not. Forston is making an assumption about the images he is going to project and uses the appellative Elenita, to address the interviewee, Elena Poniatowska. He also limits his commitment to what he is about to state with the use of perhaps. We have, then, two elements that can potentially display mitigation. 
(16) Forston: mhm ... tal vez Elenita, o más bien, de seguro, que las fotografías de Alcaide que vamos a presentar en pantalla (...) para el auditorio de Cara a Cara ..., (el título de la emisión) van a reflejar, esta dulzura, de mujer de la que estás hablando.

Forston: mhm ... maybe Elenita, or rather, for sure, the photographs of Alcaide that we will present on screen (...) for the auditorium of Cara a Cara ..., (the title of the broadcast) will reflect, this sweetness, of the woman you are talking about.

Forston, however, reformulates his commitment and emphasizes a degree of certitude. Despite the presence of two mitigating mechanisms, it cannot be stated that we have a case of mitigation here.

The tests are a methodological contribution to better assess the presence of mitigation. These three tests vary on their consistency. The absence test is the most consistent, as it is the easiest to apply. It is the least dependent on other factors, such as linguistic knowledge or identification of other elements that display mitigation. The commutation test is also consistent, but it needs the inventiveness of the analyst to convoke and organize the elements commuted on a scale. Finally, the solidarity test's consistency is less sure than the other tests and can lead to an incorrect analysis, as explained in (16). Nevertheless, in some contexts it can be helpful, especially when combined with other tests (as shown in (15)). In this sense, it needs to be highlighted that these tests become a more reliable tool when combined.

\section{Results and discussion}

A review of the corpus data revealed that, in most of the examples where the authors acknowledged that mitigation was present, the proposed tests worked. Therefore, we are going to dedicate this section to examples that are problematic because a) they can present a challenge when applying the tests; b) the presence of mitigation has been identified, but after applying the tests we reached a different conclusion; $c$ ) the researchers claim mitigation is not present, but the application of the tests indicates otherwise.

First, we will address an example that can be problematic when applying the tests. It is extracted from a political speech in the Spanish Parliament, and the trigger here is the evaluation of a statement as unfortunate:

(17a) Su señoría ha hecho una afirmación que a mí me parece de alguna manera, si me permite, desafortunada, y es que, en materia de bienestar social y en materia de iniciativa social, la situación de España es negativa.

Your honour has made a statement that seems to me in some way, if I may (say it), unfortunate, because, in terms of social welfare and in terms of social initiative, the situation in Spain is negative.

Assume our research is only interested in the use of approximatives and its possible relation to mitigation, as in expressions like in some way. If we strictly apply the absence test and only erase the approximative, the change in the utterance will be minimal and the negative content meant to be downgraded will remain mitigated. This is because in some way is not the only element displaying mitigation. As we explained in the solidarity test, mitigation is conveyed frequently by more than one device. Therefore, we will have to erase all the elements displaying mitigation and assess if the presence of the isolated element has any impact on the illocutionary force and the face management.

(17b) Your honour has made an (in some way) unfortunate statement, because, in terms of social welfare and in terms of social initiative, the situation in Spain is negative.

When the restriction of the personal evaluation (it seems to me) and the polite construction to ask for permission (if I may) disappear, the contrast becomes more evident and it is easier to observe if mitigation is present.

In other cases, the author considers mitigation to be present, but our tests do not reach the same conclusion. Consider (18).

(18) [Friend's comment on the addressee's painting] It's pretty good I suppose (Holmes, 1984, p. 350)

Holmes (1984) explains that, in language, we may find different resources to attenuate and boost illocutionary force. Mitigation usually relates to the diminution of social distance by preventing the negative effects of negative speech acts while boosting positive speech acts which increase the solidarity between participants. According to the author, the elements marked in italics in (18) convey the mitigation, in this case, of a positive social effect. However, this cannot be understood as a case of mitigation in the terms explained in this work.

If we apply the absence test (It's good), the compliment is neutral, while the use of pretty and I suppose reduce the extent to which the painting is good and the commitment the speaker adopts towards his utterance. This is a reduction, but can it be considered mitigation? Certainly, the illocutionary force is modified, but the utterance is a compliment where a neutral 
option (It's good) or an utterance with boosters would be expectable. The speaker's selection of pretty and I suppose, mechanisms that traditionally relate to mitigation, provoke a cognitive change; what is said creates a change in the addressee's mind because the expectation is not accomplished. Thus, the effect is negative ${ }^{5}$.

Finally, there were examples in our corpus where the author did not consider mitigation to be present. In some cases, our test results point in a different direction.

(19a) Grace bailó toda la noche, y Rainiero, que no es lo que se dice muy buen danzarín, tuvo serios problemas con el vuelo del vestido de su esposa,que pisó varias veces.

(Martí Sánchez and Fernández Gómiz, 2018, p. 204) Grace danced all night, and Rainier, who is not exactly a very good dancer, had serious problems with the flounce of his wife's dress, which he stepped on several times.

This example comes from a gossip book where, as the analysts of the example claim, there is no intention to preserve Rainier's face. It seems reasonable to think, as the researchers propose, that the litotes and even the use of the hedge exactly (in Spanish, the impersonal construction lo que se dice) may seek an ironic or playful lecture of Rainier's awful dancing skills. However, it is not Rainer's face that this sought to preserve, but the author's face. If we apply the absence and the commutation test combined, as in (19b), we observe that the damage to Rainier's face remains.

(19b) Grace danced all night, and Rainier, who is a bad dancer, had serious problems with the flounce of his wife's dress, which he stepped on several times.

However, the author would seem less witty and tactful - almost petty - if her critique was too direct. This would prove particularly true if, as happens later on, she contrasts Rainier's faux pas with the sensational waltz Grace Kelly and Jacques Chazot (first dancer in the Opera of Paris) performed afterwards.

All in all, the use of the tests does not entail serious problems of application. In fact, its systematic application can help the researcher during the evaluation of the data and, in the bigger picture, help homogenize the analysis of this phenomenon.

\section{Conclusion}

This paper presents a revision on the identification parameters that researchers can apply when analysing mitigation and a reflection on the three tests presented by Villalba (2018) (the absence test, the commutation test and the solidarity test) to supplement the analysis. It also shows how these tests should be applied and discusses some challenging examples found in our corpus.

As we have shown in Section 2, linguistic catalogues of mitigating devices can be helpful but are also problematic, especially in those cases where the linguistic form can convey other values apart from mitigation. In addition, the form-based analysis has ignored cases like those presented by González García and García Ramón (2017) where there is an apparent mismatch between the linguistic forms, which relate to intensification, and what operates at the illocutionary level: the mitigation of a rejection.

Since mitigation is a pragmatic phenomenon, it is not surprising that the evaluation of context is an essential criterion to assess mitigation. However, context is something as vast and complex as the main act of communication. Some authors list elements of the context may be of particular help to the analyst, such as the discursive genre or the specific interactive context. In addition, face management (own and/or others') and the reduction of the illocutionary force are valuable parameters to assess the presence of mitigation. These criteria can be useful, but are insufficient because they are too abstract and can be challenging to apply when facing data.

Thus, in addition to the traditional criteria offered by the literature, we present three tests directly oriented to the analysis of data: the absence test, the commutation test and the solidarity test. These tests can be applied independently, however, they become more robust when are complementarily applied.

The absence test, which is based on the elimination of the element that can encode mitigation, has proved to be the most consistent test. This test works well with those resources that are not in the core of the propositional content of the statement.

The commutation test is also a valuable tool for the analyst of mitigation in cases where the elimination of some elements is not possible due to the intimate relationship between the element and the propositional content. This test requires the analyst to propose alternative forms to those presented by the utterance s/he is analysing and order them on a scale. The creativity and linguistic knowledge that the analyst needs to have in order to apply this test makes it less consistent than the absence test.

Regarding the solidarity test, the analysis of the examples has revealed that it is the least consistent test to assess mitigation. However, this does not mean that it cannot be used occasionally by analysts, especially when combined with the other tests.

In short, these three tests constitute a complementary aid to better understand the ways in which the criteria presented by the literature work in both written and oral genres. For the latter, the most recent works are already beginning to find more

\footnotetext{
${ }^{5}$ Of course, this interpretation of the example is made in abstraction, because we do not know if maybe this way of making a compliment is part of the speaker's style. The author does not provide any further information.
} 
objective prosodic criteria (Cabedo Nebot, 2018) that, as they emerge, will become an invaluable support for the analyst. Likewise, another challenge that needs to be solved in terms of methodology is to assess the degree of conventionalization that some forms have experienced. Furthermore, it would be a valuable contribution to determine at what point a form ceases to develop mitigating (and, therefore, strategic) values and merely complies with the expectations of the genre.

\section{References}

Albelda, M., 2018. La variación genérico-discursiva de la atenuación como resultado de la variación de la imagen. Span. Context 15, 346-368.

Albelda, M., 2016a. Estableciendo límites entre la evidencialidad y la atenuación en español. In: González Ruiz, R., Izquierdo Alegría, D., Loureda Lamas, Ó. (Eds.), La Evidencialidad En Español: Teoría y Descripción. Iberoamericana Vervuert, Madrid/Frankfurt, pp. 75-99.

Albelda, M., 2016b. Sobre la incidencia de la imagen en la atenuación pragmática. Rev. Int. Linguist. Iberoam. RILI $27,19-37$.

Albelda, M., 2010. ¿Cómo se reconoce la atenuación? Una aproximación metodológica basada en el español peninsular hablado. In: Orletti, F., Mariottini, L. (Eds.), Des)Cortesía En Español. Espacio Teóricos Y Metodológicos Para Su Estudio. Università degli Studi Roma Tre-EDICE, Roma/Estocolmo, pp. 47-70. Albelda, M., Briz, A., 2020. In: Escandell Vidal, M.a.V., Ahern, A., Amenós Pons, J. (Eds.), Atenuación e intensificación. Pragmática. Akal, Madrid in press. Albelda, M., Briz, A., Cestero, A.M., Kotwica, D., Villalba, C., 2014. Ficha metodológica para el análisis pragmático de la atenuación en corpus discursivos de español. (ES.POR.ATENUACIÓN). Oralia 17, 7-62.

Albelda, M., Cestero, A.M., 2012. La atenuación lingüística como fenómeno variable. In: Cestero, A.M., Molina, I., Paredes, F. (Eds.), La Lengua, Lugar de Encuentro. Actas XVI Congreso Internacional de La Alfal (Alcalá de Henares, 6-9 de Junio de 2011). Servicio de Publicaciones de la Universidad de Alcalá, Universidad de Alcalá, pp. 1857-1866.

Albelda, M., Cestero, A.M., 2011. De nuevo, sobre los procedimientos de atenuación lingüística. Espanol Actual Rev. Espanol Vivo 96, 9-40.

Bazzanella, C., Caffi, C., Sbisà, M., 1991. Scalar dimension of illocutionary force. In: Zagar, I. (Ed.), Speech Acts: Fiction or Reality? IPrA, Liubliana, pp. 63-76. Briz, A., 2007. Para un análisis semántico, pragmático y sociopragmático de la cortesía atenuadora en España y América. Linguist. Espanola Actual 29, 5-40. Briz, A., 1998. Estrategias de producción-recepción (II): la atenuación en la conversación coloquial. In: El Español Coloquial En La Conversación. Esbozo de Pragmagramática. Ariel, Barcelona, pp. 143-164.

Briz, A., 1995. La atenuación en la conversación coloquial. Una categoría pragmática. In: Cortés, L. (Ed.), El Español Coloquial. Actas Del I Simposio Sobre Análisis Del Discurso Oral. Servicio de Publicaciones de la Universidad de Almería, Almería, pp. 103-122.

Briz, A., Albelda, M., 2013. Una propuesta teórica y metodológica para el análisis de la atenuación lingüística en español y portugués. La base de un proyecto común (ES.POR.ATENUACIÓN). Onomázein 28, 288-319.

Briz, A., Samper, M., 2020. A study of situational variation in Spanish spoken corpora. In: Parodi, G., Cantos, P. (Eds.), The Routledge Handbook of Spanish Corpus Linguistics. Routledge, London/New York in press.

Brown, G., Yule, G., 1983. Discourse Analysis. Cambridge University Press, Cambridge.

Brown, P., Levinson, S., 1987. Politeness. Some Universals in Language Usage. Cambridge University Press, Reino Unido.

Cabedo, A., 2016. La función de la atenuación y la configuración prosódica: un estudio a partir de un corpus de español coloquial. Rev. Int. Linguist. Iberoam. RILI 27, 55-74.

Cabedo Nebot, A., 2018. Atenuación con disminución prosódica significativa en géneros con distinto grado de planificación discursiva. Span. Context 15, 218-236. https://doi.org/10.1075/sic.00012.cab.

Caffi, C., 2007. Mitigation, Studies in Pragmatics. Elsevier, Amsterdam.

Caffi, C., 1999. On mitigation. J. Pragmat. 31, 881-909.

Cestero Mancera, A.M., 2015. La atenuación lingüística en el habla de Madrid: un fenómeno sociopragmático variable. In: Cestero, A.M., Molina, I., Paredes, F (Eds.), Patrones Sociolingüísticos de Madrid. Peter Lang, Bern, pp. 365-412.

Cock, B.D., Marsily, A., Pedraza, A.P., Rasson, M., 2018. ¿Quién atenúa y cuándo en español?: La atenuación en función del género discursivo. Span. Context 15, 305-324. https://doi.org/10.1075/sic.00016.dec.

Cotterill, J., 2003. Language and Power in Court: A Linguistic Analysis of the O.J. Simpson Trial. Palgrave Macmillan.

Czerwionka, L., 2012. Mitigation: the combined effects of imposition and certitude. J. Pragmat. 44, 1163-1182. https://doi.org/10.1016/j.pragma.2012.05.002.

Estellés, M., Cabedo, A., 2017. La atenuación fónica en entrevistas (proyecto PRESEEA) y en conversaciones (corpus Val.Es.Co): un estudio de campo. Linred: Linguist. Red 1-16.

Estrada, A., 2008. ¿Reforzador o atenuador? 'Evidentemente’ como adverbio evidencial en el discurso académico escrito”. Sintag. Rev. Linguist. $20,37-52$.

Félix-Brasdefer, J.C., 2004. La mitigación en el discurso oral de mexicanos y aprendices de español como lengua extranjera. In: Bravo, D., Briz, A. (Eds.), Pragmática Sociocultural: Estudios Sobre El Discurso de Cortesía En Español. Ariel, Barcelona, pp. 285-299.

Figueras, C., 2018. Atenuación, género discursivo e imagen. Span. Context 15, 258-280.

Fraser, B., 1980. Conversational mitigation. J. Pragmat. 4, 341-350.

Fraser, B., 1975. Hedged performatives. In: Cole, P., Morgan, J.L. (Eds.), Syntax and Semantics. Speech Acts. Academic Press, New York/London, pp. 187-210.

Garcés-Conejos Blitvich, P., 2013. Introduction: face, identity and im/politeness. Looking backward, moving forward: from Goffman to practice theory. J. Politeness Res. 9, 1-33.

Goffman, E., 1955. On face-work: an analysis of ritual elements in social interaction. Psychiatry 18, 213-231. https://doi.org/10.1080/00332747.1955. 11023008.

González García, V., García Ramón, A., 2017. Atenuación e intensificación: estrategias pragmáticas del rechazo en respuestas a invitaciones en redes sociales en línea. In: Albelda, M., Mihatsch, W. (Eds.), Atenuación e Intensificación En Géneros Discursivos. Iberoamericana Vervuert, Madrid/Frankfurt, pp. $187-204$.

Hernández Flores, N., 2013. Actividad de imagen: caracterización y tipología en la interacción comunicativa. Pragmática sociocultural 1, 1-24.

Hernández Flores, N., Rodríguez Tembrás, V., 2018. 'Lo que se debe hacer es cambiar un poco el estilo de vida’. Estrategias de atenuación en el consejo médico. Span. Context 15, 325-345.

Holmes, J., 1984. Modifying illocutionary force. J. Pragmat. 8, 345-365.

Hyland, K., 2002. Authority and invisibility: authorial identity in academic writing. J. Pragmat. 34, 1091-1112. https://doi.org/10.1016/S0378-2166(02) 00035-8.

Hyland, K., 2001. Humble servants of the discipline? Self-mention in research articles. Engl. Specif. Purp. 20, 207-226. https://doi.org/10.1016/S08894906(00)00012-0.

Hyland, K., 1996. Writing without conviction? Hedging in science research articles. Appl. Linguist. 17, 433-454.

Kern, B., 2017. "No sé si atreverme a decir...": la preterición como estrategia discursiva entre atenuación e intensificación. In: Albelda, M., Mihatsch, W. (Eds.), Atenuación e Intensificación En Géneros Discursivos. Iberoamericana Vervuert, Madrid/Frankfurt, pp. 93-110.

Kotwica, D., 2018. Verbos de percepción evidenciales en artículos científicos del siglo XIX: funciones pragmático-retóricas *. RILCE; Pamplona 34, 1154-1178. https://doi.org/10.15581/008.34.3.1154-78.

Levinson, S.C., 2000. Presumptive Meanings: the Theory of Generalized Conversational Implicature, Edición, 1st. MIT Press, Cambridge, Mass.

Levinson, S.C., 1983. Pragmatics, Cambridge Textbooks in Linguistics. Cambridge University Press, Cambridge.

Maíz-Arévalo, C., 2018. "Solo un poquito". El uso y funciones del diminutivo en español peninsular en dos grupos de Facebook. Círculo Lingüística Apl. Comunicación (CLAC) 73, 33-52. https://doi.org/10.5209/CLAC.59058. 
Markkanen, R., Schröder, H. (Eds.), 1997. Hedging and Discourse: Approaches to the Analysis of a Pragmatic Phenomenon in Academic Texts. Walter de Gruyter, Berlin; New York.

Martí Sánchez, M., Fernández Gómiz, S., 2018. Atenuación retrospectiva y reformuladores de distanciamiento como recursos suyos. Span. Context 15, 198-217. https://doi.org/10.1075/sic.00011.mar.

Martinovski, B., 2006. A framework for the analysis of mitigation in courts: toward a theory of mitigation. J. Pragmat. 38, 2065-2086.

Meyer, P.G., 1997. Hedging strategies in written academic discourse: strengthening the argument by weakening the claim. In: Markkanen, R., Schröder, H. (Eds.), Hedging and Discourse. Approaches to the Analysis of a Pragmatic Phenomenon in Academic Texts. Walter de Gruyter, Berlín, pp. $21-41$.

Meyer-Hermann, R., 1988. Atenuación e intensificación (análisis pragmático de sus formas y funciones en el español hablado). Anu. Estud. Filol. 11, 275-290.

O'Driscoll, J., 2017. Face and (Im)politeness. In: Culpeper, J., Haugh, M., Kádár, D.Z. (Eds.), The Palgrave Handbook of Linguistic (Im)Politeness. Palgrave Macmillan UK, London, pp. 89-118. https://doi.org/10.1057/978-1-137-37508-7_5.

Overstreet, M., 2011. Vagueness and hedging. In: Andersen, G., Aijmer, K. (Eds.), Pragmatics of Society. De Gruyter, Berlin/Boston, pp. 293-318.

Rowland, T., 2007. 'Well maybe not exactly, but it's around fifty basically?': vague language in mathematics classrooms. In: Cutting, J. (Ed.), Vague Language Explored. Palgrave Macmillan UK, London, pp. 79-96. https://doi.org/10.1057/9780230627420_5.

Sbisà, M., 2001. Illocutionary force and degrees of strength in language use. J. Pragmat. 33, 1791-1814.

Schmidt, R.W., 1980. Questions and politeness: strategies in social interaction. In: Goody, Esther N. (Ed.), Cambridge Papers in Social Anthropology 8. Cambridge University Press, Cambridge, pp. 100-114. https://doi.org/10.1177/003368828001100209, 1978. RELC Journal 11. Schneider, S., 2013. La atenuación gramatical y léxica. Oralia 16, 335-356.

Song, L., 2010. The role of context in discourse analysis. J. Lang. Teach. Res. 1, 876-879.

Swales, J., 1990. Genre Analysis: English in Academic and Research Settings. CUP, Cambridge.

Thaler, V., 2012. Mitigation as modification of illocutionary force. J. Pragmat. 44, 907-919.

Villalba, C., 2018. Atenuación: algunas claves metodológicas para su análisis. Normas 8, 306-316. https://doi.org/10.7203/Normas.v8i1.13277.

Villalba, C., 2017. Actividades de imagen, atenuación e impersonalidad. Un estudio a partir de juicios orales españoles. Peter Lang, Frankfurt am Main.

Cristina Villalba Ibáñez is an Associate Lecturer in Spanish at Universitat Jaume I (Spain). Her research interests are in mitigation, legal language and (im) politeness. Recent research publications have included articles on: impersonality, evidentiality, pragmatics in legal discourse, and Spanish as a second language. 